$1 \mathrm{H}-03$

\author{
感性工学に基づく \\ ノック式ペンシルデザインの分析 \\ ○渡辺 堅二, 松原 行宏, 長町 三生 \\ (広島大学 工学部)
}

\title{
Analysis of mechanical pencil design based on Kansei Engnieering
}

Kenji WATANABE,Yukihiro MATSUBARA and Mitsuo NAGAMACHI

(Faculty of Eng.,Hiroshima Univ.)

\section{1 はじめに}

消費者の嗜好の多樣化が年々進み，商品を提供 する企業は，新しいデザインを次々と生み出す研 究を日タ続けている. 日用品の一つであるノック 式ペンシルは，その最も身近な例の一つと考えら れ，企業は样々なデザインや機能を兼ね備えたも のを市場に数多く送り出してきた。しかし，その 中に消費者のニーズを十分に満たしている商品は 非常に少ない。ゆえに，消費者の満足度をより高 くするためには，その商品に対する人間のイメー 汭を的確に抽出する事が, 商品の開発等において 大変有効な手段になると考えられる。 そこで本研 究では，人間の感性やイメージなどの心理的な要 因を具体的な物理的デザインに翻訳する感性工学1 の手法を用いて，ノック式ペンシルのデザイを 構造的に明らかにすることを目的としている.

\section{2 感性工学実験}

\section{1 実験環境}

(1)感性ワード：専門家の意見を参考にしてノック 式ヘンンシルのデザイン及び機能性を表現するのに 適当と思われる形容詞75対を選出

(2)デザイン要素：6アイテム，16カテゴリに分割 (表 1 参照)

(3)サンプル：7サンプル

(4)被験者：1グルーブが専門家ら4〜5人の集団5グ ループ

\section{2 実験方法}

デザインから受けるイメージを，75対の感性ワ 一ドより5段階SD法で評価させた。 テータは，2つ の分析方法により解析を行った。 まずノック式べ ンシルの感性を構成する因子を把握方るために因 子分析を行い，次に全ての形容詞対に対して数量 化理論第I 類”による分析を行った. 数量化理論第 I 類による分析は，説明変数がサンブルのアイテ
ム・カテゴリであり, 外的基準は各サンブルでの 評価値の平均である. 本実験ではサンプルが少な いため, デザインアイテムを3つのパーツに分け， そのパーツごとの分析を行った（図 1 参照）.

\section{3 分析結果と考察}

(1) 因子分析結果

因子分析による結果は, バリマックス回転を行 いそこから抽出できた因子は6つであった。第 I因 子は，「高級な」という形容詞に代表される“高 級感の因子”となった，以下第V因子まで“太さ の因子”“鮮やかさの因子”“接触間の因子” “長さの因子”“独創性の因子”として抽出でき た.つまり，ノック式ペンシルのデザインの感性 は以上6つの因子から構成されているといえる。

\section{（2）数量化理論第।類による分析結果}

数量化理論第 I 類による分析の例として形容詞 対「本格的でない一本格的な」の結果と「書きに くい一書きやすい」の結果を表1と表 2 に示す. これより「本格的な」に大きな影響を与えている アイテムは, パーツ1では偏相関係数の高い“ノッ クカバー\&キャッブ"といえる. 同様にバーツ 2 については“クリップ”，パーツ3については “使用色”となった。特に色彩に関して，無色彩 を基調とするものが「本格的な」イメージに大き く関与する結果が得られた。これは一般的概念と 一致した結果といえる。また逆に，「本格的な」 イメージに負の影愫を与えるノック式ペンシルの デザインとは，2色が用いられた青系の胴体を持つ ものだと言える.

さて一方の「背きやすさ」については，先端部 分は“ノックカバー\&キャップ”の偏相関係数が 高かった．同栚に胴体では，“クリップ”，色関 係では，“使用色”となった。表 1 と表 2 より両 者を比較すると，「本格的な」イメージなるのと

「堙きやすい」ものはおおよその部分において一 致した結果が得られたことから，どちらかの形容 
詞にて評価を行うことで，どちらも満たす商品が 得られると考えられる。しかし，細部において， カテゴリスコアを比較する上で，特に胴体の太さ に関しては，「書きやすさ」を重視すれば太めな ものが望ましく，「本格的な」点を重視するなら ば細めなものが良いと考えられる。

各バーツごとに, その全ての形容詞対について 重相関係数の分布を調べた（表3）。これより， パーツ2の胴体が統計的に最も信頼性の高い要素 であることがわかった。一方, 低い平均値を示し た“先端部分”は，実際にノック式ペンシルを持っ た場合あまり目立たない情報である。つまり，色 などといった目立つ情報に対して左右されたと考 えられる.

また，各アイテムごとに，そのすべての形容詞 対について偏相関係数の分布を調べた（表 4). これより，“キャップ”が最も高い值にて推移し ていたことがわかった.つまりユーザは、ノック 式ペンシルのデザインを考える上で，キャップに 重きを置く傾向が強いと考えられる。

\section{3 まとめ}

本研究では，ノック式ペンシルの構成因子を明 らかにした上で, デザイン要素と感性との結びっ きを調查・分析し，デザインを考える上で統計的 に重要な要素を明示した。しかし，サンプルが比 較的少ない実験であったので，より人間の感性と の関係を明確かつ信頼性の高いものとするために も，サンプルを增やした上でアイテムムカカテゴリ の再検討が必要と考えられる，また，本来人間の 感性は非線形的な特性を示すのに対し，本研究で は線形的に扱った。よって感性の構造をより明確 にするためにも，線形モデル以外の分析方法も考 える必要性があると考えられる。

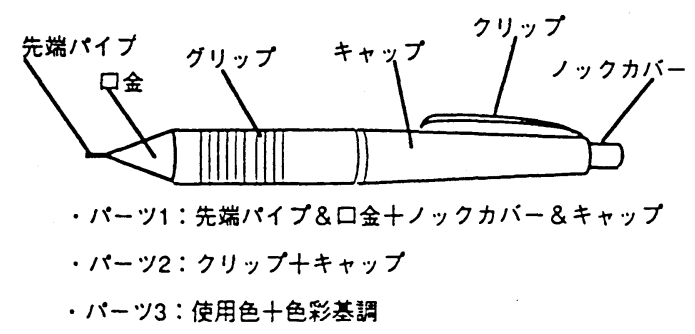

図1ノック式ペンシルの搆成と名称
表 1 アイテム・カテゴリと解析結果（その1）

「本格的でない一本格的な」

\begin{tabular}{|c|c|c|c|c|c|c|c|}
\hline パーツ1 & フイテム & \multicolumn{3}{|c|}{ tis } & 伤相制 & 27 & 重相为 \\
\hline \multirow[t]{3}{*}{ 先橦部分 } & 先端 $n^{*}\left\{7^{*} \& \square\right.$ 金 & \multicolumn{3}{|c|}{$\begin{array}{l}\text { 告出型型 } \\
\text { 型稆型 }\end{array}$} & 0.274 & $\begin{array}{r}-0.171 \\
0.228\end{array}$ & \multirow[t]{3}{*}{0.700} \\
\hline & 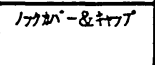 & 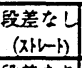 & \multicolumn{2}{|c|}{ 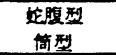 } & 0.686 & $\begin{array}{l}257 \\
0.657\end{array}$ & \\
\hline & & 段差あり & \multicolumn{2}{|c|}{ 简型 } & & $-0.742 \mid$ & \\
\hline パーツ 2 & フイテム & \multicolumn{3}{|c|}{$\operatorname{tin}^{\circ}$} & 俋相関 & 37 & 重相関 \\
\hline \multirow[t]{6}{*}{ 周体 } & クリンフ & \multicolumn{3}{|c|}{ 一体型 } & 0.714 & -0.385 & \multirow[t]{6}{*}{0.925} \\
\hline & & & 䗑型 & & & 0.514 & \\
\hline & \multirow[t]{4}{*}{ キャンフ } & 金属 & 敖受 & 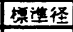 & \multirow{4}{*}{0.653} & .471 & \\
\hline & & \multirow[t]{3}{*}{ 餗脂 } & 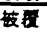 & 槙涑径 & & -0.028 & \\
\hline & & & & 聖太径 & & -0.128 & \\
\hline & & & 透明 & 棲準径 & & .0 .728 & \\
\hline パーツ3 3 & フイテム & \multicolumn{3}{|c|}{ tis } & 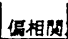 & 27 & 重相盟 \\
\hline \multirow[t]{2}{*}{ 色開保 } & 使用色 & \multicolumn{3}{|c|}{$\begin{array}{l}1 \text { 色 } \\
2 \text { 色 }\end{array}$} & 0.862 & $\begin{array}{r}-0.661 \\
0.881\end{array}$ & \multirow[t]{2}{*}{0.870} \\
\hline & 色彩基調 & \multicolumn{3}{|c|}{$\begin{array}{l}\text { 赤系 } \\
\text { 肯系 } \\
\text { 無色衫 }\end{array}$} & 0.759 & $\begin{array}{l}-0.081 \\
-0.624 \\
0.746\end{array}$ & \\
\hline
\end{tabular}

表 2 アイテム・カテゴリと解析結果（その 2 )

「書きにくい一書きやすい」

\begin{tabular}{|c|c|c|c|c|c|c|c|}
\hline \multirow{3}{*}{$\frac{\text { パーツ1 }}{\text { 先端部分 }}$} & \multirow{2}{*}{ 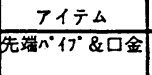 } & \multicolumn{3}{|c|}{ カテコリリ } & 遇相园 & 지 & 重相間 \\
\hline & & \multicolumn{3}{|c|}{ 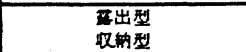 } & 0.141 & $\begin{array}{l}-0.054 \\
0.071\end{array}$ & 0.814 \\
\hline & 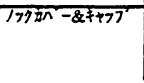 & 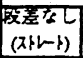 & \multicolumn{2}{|c|}{ 型 } & 0.314 & $\begin{array}{l}0.964 \\
0.339\end{array}$ & \\
\hline & & \multirow{2}{*}{\multicolumn{3}{|c|}{ カテゴリ }} & \multirow{3}{*}{ 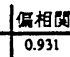 } & & \multirow{3}{*}{$\frac{1}{0.1 \text { 相闻 }}$} \\
\hline パーツ2 & フイテム & & & & & スコ7 & \\
\hline \multirow[t]{5}{*}{ 恓作 } & গリッフ & \multirow{2}{*}{\multicolumn{3}{|c|}{ 一伤立 }} & & -0.347 & \\
\hline & & & & & & 0.867 & \\
\hline & \multirow[t]{3}{*}{ キャッフ } & 金品 & $\frac{1}{3} \overline{2}$ & 栖整径 & \multirow[t]{3}{*}{0.885} & 0.026 & \\
\hline & & \multirow[t]{2}{*}{ 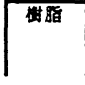 } & 拱高 & 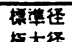 & & 0.061 & \\
\hline & & & D明 & 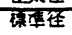 & & -0.867 & \\
\hline パーツ3 & フイテム & \multicolumn{3}{|c|}{ カテゴリ } & \multicolumn{2}{|l|}{ |促相间 } & 重相閶 \\
\hline \multirow[t]{4}{*}{ 色觌保 } & 被用色 & \multirow{2}{*}{\multicolumn{3}{|c|}{$\begin{array}{l}1 \text { 色 } \\
2 \text { 色 }\end{array}$}} & \begin{tabular}{|l|}
0.970 \\
\end{tabular} & 0.837 & 0.974 \\
\hline & & & & & & 0.944 & \\
\hline & 色祄勘部 & \multirow{2}{*}{\multicolumn{3}{|c|}{$\begin{array}{l}\text { 赤系 } \\
\text { 等 } \\
\text { 每色柇 }\end{array}$}} & 0.628 & 0.020 & \\
\hline & & & & & & $\begin{array}{l}-0.694 \\
0.663\end{array}$ & \\
\hline
\end{tabular}

表 3 重相関係数の平均と分散

\begin{tabular}{|c||c|c|c|}
\hline & 笛囲 & 平均 & 分散 \\
\hline パーツ1 & $0.153 \sim 0.962$ & 0.6767 & 0.0328 \\
\hline パーツ 2 & $0.153 \sim 0.998$ & 0.8291 & 0.0212 \\
\hline パーツ3 & $0.220 \sim 0.992$ & 0.7232 & 0.0445 \\
\hline
\end{tabular}

表 4 偏相関係数の平均と分散

\begin{tabular}{|c|c|c|c|}
\hline & 範囲 & 平均 & 分散 \\
\hline 先端パイプ\&口金 & $0.057 \sim 0.853$ & 0.3582 & 0.041 \\
\hline ノックかパー\&キャップ・ & $0.134 \sim 0.962$ & 0.6281 & 0.050 \\
\hline クリップ & $0.071 \sim 0.998$ & 0.6463 & 0.081 \\
\hline キャップ & $0.084 \sim 0.996$ & 0.7639 & 0.034 \\
\hline 使用色 & $0.031 \sim 0.985$ & 0.5628 & 0.083 \\
\hline 色彩基調 & $0.099 \sim 0.986$ & 0.6582 & 0.055 \\
\hline
\end{tabular}

【参考文献】

1) 長町三生：「感性工学」，海文堂 (1989).

2) 小林龍一：「数量化理論入門」，日科技連出版 社(1981). 